\title{
Treading lightly: regularised migrant workers in Europe
}

\begin{abstract}
This study draws on qualitative interviews with regularised, semi-documented and undocumented migrant workers in seven EU countries, each with a different experience of implementing regularisations as a policy tool to manage undocumented migration. The article examines the relationship between a regularised or documented status and work conditions, including access to employment and social rights. It sheds light on the importance of labour market structures in creating opportunities or otherwise for those with newly acquired legality in the host country. The complex impact of migrant status alongside the importance of a strong industrial relations system to enforce rights at work is revealed.
\end{abstract}

Key words: regularisation programmes, undocumented migration, regularised migrants, work conditions

\section{Introduction}

For over a decade, the dominant migration discourse in Europe has been persistently dominated by political positions in favour of preventing and reducing undocumented migration, with very little consideration of managing the issue and therefore acknowledging the precariousness and vulnerability of undocumented migrants (McGovern, 2014). Securitization measures subjugate the current European Union migration management agenda, aimed at protecting borders, 'stopping' irregular migration, and facilitating return and readmission, against the backdrop of humanitarian responsibility of saving lives and demonstrating solidarity (European Commission, 2018). 'Illegal migration' is often associated with criticism of relaxed border controls, cross border criminal activity and ultimately it is perceived as a threat to national security. It is argued that 'the political significance of irregular migration far outweighs its numerical significance' (Koser, 2016: 52). Consequently, undocumented migration has attracted the interest of various actors within the European Union and its Member States. These include government departments being created especially in order to control migration; non-governmental organisations and other activists working on the protection of human and migrant rights (McKay et al., 2011); employers wishing to ensure a constant pool of 'flexible' or 'cheap' labour; and travel companies concerned with potential sanctions for transporting people without documents (Bloch and Chimienti, 2011). Despite the new pro-securitization rhetoric within the EU, some member states have opted for migration management rather than prevention, resorting to the implementation of regularisation programmes - a policy measure long recognised as the most controversial, politically loaded and poorly understood by policy makers (McKay et al., 2011). The 'REGINE' study (2009) defines regularisation programmes as a time-limited procedure, which is implemented outside the regular migration policy framework, usually involving a large number of applications. Mc Govern 
(2014) posits that regularisation programmes aim to bring unauthorized immigrants into mainstream society, either for economic or humanitarian reasons, with a long-term goal of reducing irregular immigration and curtailing the underground economy. Over 40 regularisation programmes have been implemented in Europe and the US (McKay et al., 2011: 75) and more than five million people have been regularised since the 1980s, mainly in Southern Europe (European Commission, 2016). Yet, there is still limited evidence on the impact of such policy measures for improving the working lives of migrant workers and facilitating their access to employment and social rights in the host country.

This article explores the consequences of a regularised migrant status through a cross-national European study, paying particular attention to migrant work conditions and opportunities. Migrants with a regularised status in the host country are defined as those foreign-born nationals who had either entered the country illegally or had overstayed their visas, remained unauthorized for a period of time, then took part in a state initiative to regularise their status and as a result have acquired legal right of residence and work.

The article begins with an outline of the policy context by providing an overview of the regularisation programmes as a policy measure to tackle irregular migration and continues with a review of the literature on the impact of regularised status on work. Secondly, we explain the methodological issues that arose in conducting a collaborative European project. Thirdly, the empirical findings are presented, discussing the regularisation experience and its impact on migrants' working lives and their access to rights in the host country.

\section{Regularisation programmes and the impact of regularised status on work}

\section{Regularisation as a policy tool: the pros and cons}

The regularisation of undocumented migrants has long been recognised as a measure of last resort. 'When all else fails, governments may have to resort to amnesty measures to remove the threat of expulsion that hangs like the sword of Damocles over the heads of foreigners', warned Bohning (1996:82) from the International Labour Organisation. The United States conducted its last major legalisation programme more than three decades ago, in 1986. Since then, the number of the unauthorised immigrants have grown from an estimated 5 million to approximately 11 million in 2015 (Passel and Cohn, 2016). Subsequent US administrations have favoured increased immigrant detention and deportations as the main policy tools for managing the unauthorised immigrant population, targeting the workplace as a primary site for such enforcement practices (Cook et al., 2018). Similarly, in Europe, the political arena is overwhelmingly opposed to mass regularisations. In its Final Communication (European Commission, 2015: 68) the Commission makes no reference to regularisation as policy response and at most favours what it calls 'targeted regularisation of irregular migrants for whom there is labour market demand', thus favouring regularisation only where it responds to labour market needs rather than to the needs of exploited workers. The European Parliament has recently made the connection between the absence of legal routes and undocumented migration stating:

The lack of legal migration channels clearly encourages irregular migration, since the regularisation of irregular migrants remains the main way to access the EU labour market for reasons of employment (2016:17). 
Opponents of regularisation argue that it acts as a 'pull' to draw new migrants. In practice the results are mixed, with some regularisations leading to new movements of migrants, for example, Greece after the 1998 regularisation programme and the USA, after the mass amnesty of 1986 (Bansak, 2015). However, there is also a strong body of literature that does not link regularisation with increased undocumented migration (Larramona and Sanso-Navarro, 2015; Papademetriou and Sommerville, 2008; Council of Europe Assembly, 2007). Opposition to regularisation is at odds with that of many (although not all) NGOs and with the trade unions who advance regularisation as a humanitarian response to the condition of the undocumented, particularly in cases where workers have been undocumented over long periods, perhaps contributing taxes while not receiving any benefits (MRCI, Press release, 2016). The European Trade Union Confederation has called on the EU to have 'a clear strategy for regularisation of migrants and to fight their exploitation within the informal economy' (ETUC, 2014).

\section{Legal status and access to formal employment}

At first sight regularisation appears to be the logical demand on states to deal with the acknowledged problems of 'undocumentedness'. Legal status is assumed to provide access to the formal labour market where conditions are likely to be better and more highly regulated and thus safer and less abusive. However, existing research suggests more nuanced results. The impacts of regularisation on work were mixed for different countries. For example, a study by Ruhs and Wadsworth (2018) found that the removal of employment restrictions for Bulgarians and Romanians in the UK, in January 2014, had shifted many formerly 'self-employed' individuals into paid employment but had little to no impact on any other labour market outcomes such as hours worked, earnings and the nature of the job. An analysis of Italy's 2002 legalisation initiative showed that the mere prospect of a change in legal status positively affected labour market conditions. Unauthorised immigrants who were potentially eligible for legal status under the amnesty programme had a significantly higher probability of being employed compared to undocumented immigrants who were not eligible. Menjivar and Lakhani (2016), in their study of migrants in the USA who have gone through a process of legalisation, suggest that the ability of migrants to transform their lives through engaging in a legalisation process is responsive to state and societal attitudes to migrants, so that regularisation of itself is insufficient to allow integration and labour market outcomes equal to those of the non-migrant worker. Similarly, in the context of South Africa, Thebe (2016) argues that ad hoc approaches to immigration policy (such as regularisation) fail to take account of migrants themselves, in terms of their strategies and needs and indeed in terms of migration patterns and flows. Bansak also found that regularisation had the potential to attract more undocumented migration and that it might force greater levels of competition between established and recently regularised migrants.

Labour market outcomes for regularised migrants may also differ by ethnicity and by gender. For example, in the USA, women who regularised their migration status were less likely than men to improve their work situation, at least in the short-term (Cobb-Clark and Kossoudji, 1999). Similarly, for Spain, Arango and Finotelli (2009) reported a trend for a change of employment sector of regularised migrants, from agriculture to construction (for men) and from domestic work to bars and restaurants (for women), whereas, in the South of Italy, employment opportunities for regularised migrants almost doubled in construction and agriculture.

There is still insufficient evidence to explain the exact mechanisms that operationalise opportunities for legalised migrants. Undoubtedly, some changes may occur in workers' 
behaviours and their strategies on the labour market as a result of not fearing deportation. Other changes may occur in employers' attitudes towards legalised workers.

\section{Methodology and a cross-national research design}

This article draws on findings from a combination of primary and secondary data. Secondary data involved extensive deskwork on regularisation programmes in Europe. Secondary research has been conducted as supplementary to primary research and as a means of updating its finding. Fieldwork carried out in 2008-2009 by respective project partners in seven European countries (Austria, Belgium, Denmark, the UK, Italy, Spain and Bulgaria). Qualitative interviews were conducted with 211 migrant workers who were either undocumented at the time of the research or had regularised their status but had held an irregular status at some point during their stay in the host country. As this was a cross-national European project, data was collected in different country contexts following an agreed methodology, including the compilation of a glossary of terms and ethical guidelines. The surveyed countries differed in terms of their experiences with regularisation programmes ${ }^{1}$. Opportunities for regularisation existed to any significant extent only in Spain, Italy and Belgium while a few had claimed asylum in the UK, Austria or Bulgaria $^{2}$. Each partner conducted 10 interviews with stakeholders and 30 interviews $^{3}$ with migrant workers. A non-probability sampling strategy was applied through snowballing, gatekeepers and existing community contacts. An attempt was made to use multiple-entry points to capture a variety of migrant experiences, indicative of the regularised population in the respective European countries. The sample was stratified by gender aiming at least 40 per cent of the interviewees to be female. The interviews were conducted in the language of the destination country or in a language otherwise common to researcher and interviewee. Interviews were recorded, given that the research ethics in relation to confidentiality had been clearly explained. All partners provided interview notes in English. It was considered appropriate to offer small incentives to interviewees as a 'thank you' for their time. As one of the authors has argued previously (McKay and Snyder, 2009), there is no reason why an individual's story would be any more or less honest because a small incentive is available.

The final sample comprised 68 undocumented workers (32\%), 13 (6\%) were semidocumented (defined as those who were working in breach of their residency status) and 125 $(62 \%)$ had legalised their status in the host country. Most of the legalised migrants in the sample were women, concentrated in the 25-49 age group, with completed secondary education. Table one provides detailed information on the status, gender, age and educational background of the interviewees.

\section{Table 1 Distribution of Migrants by Legal Status (at interview date), Gender, Age and Education}

\footnotetext{
${ }^{1}$ Refer to Annex A and Annex B of the REGINE report (2009).

${ }^{2}$ The latter are referred to as documented (as opposed to regularised) in the analysis.

${ }^{3}$ Researchers in Austria conducted 31 interviews.
} 


\begin{tabular}{|c|c|c|c|c|}
\hline & Undocumented & $\begin{array}{l}\text { Semi- } \\
\text { documented* }\end{array}$ & $\begin{array}{l}\text { Regularised/ } \\
\text { documented }\end{array}$ & Total \\
\hline $\begin{array}{l}\text { Age group: } \\
18-24 \\
25-34 \\
35-49 \\
\text { Over } 50 \\
\text { Total: }\end{array}$ & $\begin{array}{l}11(16.2 \%) \\
27(39.7 \%) \\
25(36.8 \%) \\
5 \quad(7.4 \%) \\
68(100 \%)\end{array}$ & $\begin{array}{l}2(15.4 \%) \\
4(30.8 \%) \\
6(46.2 \%) \\
1(7.7 \%) \\
13(100 \%)\end{array}$ & $\begin{array}{l}7(5.4 \%) \\
52(40 \%) \\
56(43.1 \%) \\
15(11.5 \%) \\
130(100 \%)\end{array}$ & $\begin{array}{l}20(9.5 \%) \\
83(39.3 \%) \\
87(41.2 \%) \\
21(10.0 \%) \\
211(100 \%)\end{array}$ \\
\hline $\begin{array}{l}\text { Gender: } \\
\text { Male } \\
\text { Female } \\
\text { Total: }\end{array}$ & $\begin{array}{l}38(55.9 \%) \\
30(44.1 \%) \\
68(100 \%)\end{array}$ & $\begin{array}{l}12(92.3 \%) \\
1(7.7 \%) \\
13(100 \%)\end{array}$ & $\begin{array}{l}62(47.7 \%) \\
68(52.3 \%) \\
130(100 \%)\end{array}$ & $\begin{array}{l}112(53.1 \%) \\
99(46.9 \%) \\
211(100 \%)\end{array}$ \\
\hline $\begin{array}{l}\text { Education: } \\
\text { Minimum } \\
\text { Secondary } \\
\text { University/tertiary } \\
\text { Professional } \\
\text { qualification } \\
\text { Total: }\end{array}$ & $\begin{array}{l}24(35.8 \%) \\
30(44.8 \%) \\
10(14.9 \%) \\
3(4.5 \%) \\
67(100 \%)\end{array}$ & $\begin{array}{l}3(23.1 \%) \\
6(46.2 \%) \\
2(15.4 \%) \\
2(15.4 \%) \\
13(100 \%)\end{array}$ & $\begin{array}{l}13(10.4 \%) \\
59(47.2 \%) \\
35(28.0 \%) \\
18(14.4 \%) \\
125(100 \%)\end{array}$ & $\begin{array}{l}39(19.5 \%) \\
95(46.3 \%) \\
47(23.0 \%) \\
23(11.2 \%) \\
205(100 \%)\end{array}$ \\
\hline
\end{tabular}

Similar characteristics were recorded in more recent regularisation programmes in Spain, reflecting an increase in female migration from Eastern Europe (REGINE, 2009). The highest number of interviewees in the total sample who benefited from these programmes was in Italy, where over half had participated in a regularisation programme and had managed to retain their legalised status. Similarly, in Spain, six people in the sample managed to regularise their status through regularisation programmes and retain it. Others had initially arrived as visitors, students or work permit holders and had subsequently become undocumented, failing to meet the necessary requirements for renewal of their permits.

\section{Regularisation and labour market terms and conditions}

Our data reveals relatively high levels of employment among migrants in the cross-national sample, with just four per cent unemployed and in search of a job. Most of the surveyed regularised migrant workers were employed in the primary sector; some 25 were working in the informal sector and 10 were in the 'grey' are between the two (Table 2).

\section{Table 2 Distribution of Migrants by Sector of Employment and}

\section{Legal Status}

\begin{tabular}{l|c|c|c}
\hline Legal status & $\begin{array}{c}\text { Primary sector } \\
\text { employment }\end{array}$ & $\begin{array}{c}\text { Informal sector } \\
\text { employment }\end{array}$ & $\begin{array}{l}\text { Between primary and } \\
\text { informal sector } \\
\text { of employment }\end{array}$ \\
\hline & $8(8.2 \%)$ & $53(59.6 \%)$ & $2(16.7 \%)$ \\
Undocumented & $2(2.0 \%)$ & $11(12.2 \%)$ & $0(0.0 \%)$ \\
Semi-documented & $88(89.9 \%)$ & $25(28.1 \%)$ & $10(83.3 \%)$ \\
Documented/ Regularised & $98(100 \%)$ & $89(100 \%)$ & $12(100 \%)$ \\
Total & & & \\
\hline
\end{tabular}

Source: Fieldwork, 2008-2009 
Our data reveals that work in the primary sector employment does not always involve regulated employment and compliant employers. Some interviewees spoke of employers who were not declaring their actual hours of work to the authorities, which was the reason for them to not contribute to tax or social insurance payments. They expressed concerns that such irregularities may pose an obstacle to their renewal of the work permits. Across the seven EU countries surveyed, these exceptions were often found in the cleaning sector, both in private households and industrial cleaning, construction and agriculture.

Night work was often associated with undocumented or irregular work, as night work, at least psychologically, provided anonymity and was seen as less 'out in the open', in other words more 'hidden' employment. Some Turkish-speaking regularised interviewees in the UK, reported initial informal employment primarily in the textile sector, a precise reflection of the dual labour market theory (Piore, 1980). It was characterised as hard work, under poor conditions, and with a high degree of harassment and bullying. Two of the women talked of ongoing health problems as a result of hard and repetitive work. 'We were a cheap and silenced group of unsafe migrants' (Turkish female, UK). Migrant workers with limited knowledge of the host country's language, employment legislation or employment conditions tended to concentrate in firms at the bottom end of the market, which offered lower wages and riskier work conditions. This duality in the economy is sustained by differences in wages and capital costs between formal and informal sectors. Low wages are driven by the management practices and employer demand for flexibility. Therefore employers can change pay and work conditions and they can fire or hire staff based on fluctuating demands. Such practices have been associated with the expansion of precarious types of employment throughout Europe in sectors where employment rights and welfare benefits are low and often non-existent (Siegmann and Schiphorst, 2016). Despite increasing economic uncertainty and tightened immigration controls across the EU Member States, informal employment has grown, often described as a 'structural phenomenon', 'reproducing external hierarchies, with local workers at the top, regularised migrants under them, and undocumented workers at the bottom' (McKay et al., 2011: 120-121). In other words, the falling rate of profits has produced cyclical and structural worsening of work conditions, particularly for those on the margins of the national economies.

For other migrant workers in the sample, employment in the informal sector was the result of their own preferences. African migrants regularised in France and working in the UK talked about their voluntary engagement in informal employment because of its freedom and untaxed income (enabling them to get higher 'cash' earnings). 'I want to be free. I don't want to be stuck in legal work', a young Moroccan man stated. It can be argued that these are life strategies based on quality of life decisions as opposed to survival strategies. Yet, our data indicates that regularisation does not always result in increased opportunities or acceptable outcomes for migrants and that for these to occur there needs to be a complex interweaving of legal status and labour market regulation to deliver the economic and social conditions that enable those who have been undocumented to prosper in safety and security. It is, of course, true that with regularisation workers gain access to labour rights. A young Turkish woman came to Austria on a visa for an arranged marriage with an Austrian. Her legal status was tied to her husband. She worked as a cleaner in a Turkish restaurant. Following her divorce, she slipped into irregularity. The owner of the Turkish restaurant applied for a work permit for her, which effectively regularised her status. Regularisation had given her a sense of greater security and she had full 
access to health and welfare benefits. However, rather than providing her with improvements in working conditions, it had obliged her to accept even harsher ones.

The work conditions did not change in the restaurant as I was doing the same job but I gained social and health security rights. In exchange for the regularised status, though, I had to agree with not being paid a 13th and 14th monthly salary. And, I had to work as a slave, without a day off and without paid overtime. (Turkish woman, Austria)

There are a number of reasons why this is the case. First, undocumented and legalised migrants are over-represented in precarious forms of employment and it is generally in these forms of employment that workers are excluded from employment rights because they do not meet eligibility requirements based around the concept of 'standard' or typical workers. We argue that the elimination of informal economy work is essential to ensure that workers are not pulled into it through their need to work. Second, regularisation is difficult to acquire without employer support, placing the employer in a dominant position of power. The right to remain, as well as the right to work, is dependent on the migrant maintaining good relations with the employer. This discourages challenges to employers who ignore labour laws. Third, where regularisation programmes have been implemented, their 'success' (if measured by improved labour market terms and conditions) is dependent on a number of extraneous factors, including the power of key actors, such as trade unions, the embeddedness of employment protection legislation and its enforcement mechanisms (McKay et al., 2011) as well as the level at which regularisation occurs, whether national or local (Visser, 2016).

It is only a combination of worker power and time, together with regularisation and post regularisation enforcement measures that can promote improvements in working conditions (McKay et al., 2011). Our research bears out the assertion that movements out of the sectors of undocumented employment are a key requirement to improve working conditions and where such movements are limited then work improvements are less likely. When such movements do take place it is also difficult to ascertain whether this is due to a status change or simply the outcome of the passage of time and length of migration, bringing with it better knowledge of the labour market (Bloch and McKay, 2016).

Milan, a construction worker in Austria, had legalised his status through marriage. However, one consequence was that the work contracts he was offered had become shorter and employment became more unstable. Employers were less willing to employ him once he had legal status. In Italy our data showed that bonded labour (a form of debt labour) was a condition of debt, which was not limited to debt on migration. Debts also are incurred in the purchase of bogus employment contracts to secure work permits, in agreements to work in return for work contracts and also in attempts at family reunification. All require large sums of money which are traded in return for bonded labour. Such labour inevitably is excluded from employment protection. A similar trajectory was observed among the UK interviewees and it was only for a minority of interviewees that a change in status had been accompanied by improved employment conditions. For example, Jamal - an interviewee in the UK- managed to legalise his status winning an appeal on his rejected asylum application in the UK but continued to work in the semi-formal economy, in the shop selling mobile phones, and a significant part of his work was undeclared. 
There are also examples of where regularisation had opened up opportunities to move sectors of employment, from less to more secure employment. Our data has shown that in Spain there was a tendency to move to sectors of employment deemed less vulnerable, with half having achieved a change of sector. Pepa from Bulgaria, had moved into professional work, once regularised. Having begun working as a cleaner in private households, once she had regularised her status, she found a job in a dental practice. With support from the practice she had qualified as a nurse. Her experience was that a regularised status had provided her with a professional opportunity. Samir, having regularised his status in Spain, had been able to study and to work and through his trade union activities he had eventually obtained a trade union organiser's job. Similar findings come from a study of the 2000 Belgian regularisation programme (Dzhengozova, 2009). Those who are regularised also no longer have to live with the fear of deportation.

While many of those interviewed in the sample referred to bullying, harassment and discrimination at work on the grounds of their undocumented status, it was only black legalised migrants who discussed their experiences of differential treatment at work. It was noted that discrimination occurred not only because of their migrant status but also on the grounds of their ethnicity, and it was only black migrants who spoke of experiencing racism. A male from Benin, West Africa, reported how he had faced a lot of discrimination in the Austrian labour and housing markets, even though he was regularised. He had been discriminated against by a middle manager who had objected to his being employed at the supermarket where they both worked and he told the members of our research team that without the intervention of a friend, he would have lost his job.

She said that she did not't want any black people to work in this shop and that I had to be dismissed. Then the friend of my father who is my boss in the branch answered: "If you want to dismiss this black worker you also have to dismiss me and then she denied it". Later my boss called a higher boss in the headquarters and made a complaint about her and from this moment on she left me alone. (Beninese male worker, Austria)

One in four of the black migrants interviewed in Belgium also raised the issue of race discrimination. A migrant from Niger referred to labour market discrimination focusing on black migrants. A journalist from Burkina Faso, West Africa, expressed a conviction that he would never find a job commensurate with his qualifications, making the point that the Belgian national broadcasting society did not employ any black journalists. His experience had led him to concede that 'Belgian society does not support the hiring of black people in regular employment'.

Individuals sometimes found it difficult to accept that they had been treated badly on the grounds of their ethnicity, as this interview demonstrates:

It was first job I had where I heard racist slurs from a colleague. That's where I heard the first racist slurs. He said a really ugly word to me that I can't repeat, I don't want to . . .I keep this thing inside me. . . .It's a disappointment I had, I didn't think that in a country like Italy. (Senegalese female, Italy) 
Discrimination on the grounds of ethnicity was also encountered in countries with very recent migration histories like Bulgaria, with one in six black migrants interviewed having directly experienced race discrimination. For example, a Guatemalan woman had experienced discrimination on several occasions when her colleagues would call her 'the yellow', an allusion to her skin colour. Even in the Northern European countries of Belgium and Denmark, race discrimination was an issue. A 24-year-old Nigerian woman, interviewed in Copenhagen, spoke of the 'disadvantages' of being of black origin in Northern Europe:

I want to go to the UK or USA so people can not so easily see that I am African. It is very easy to identify people in Europe because everybody is white and black people are having a tough time.

However, even though the comment from the Nigerian woman in Copenhagen (cited above) might suggest that the UK was a better destination for black migrants, there too the issue of discriminatory treatment was raised. A Nigerian male spoke of discrimination at work based on colour. "Black people on security sites are rarely made supervisors; white people are preferred for these jobs". He had also experienced discrimination for racist reasons on another occasion when he had been interviewed and accepted for a job over the phone, but when he presented himself in person the company withdrew the job offer.

There remain caveats in relation to regularisation programmes, in particular those that are presented as 'one-off' regularisations as such regularisations, 'set the meter at zero' (McKay et al., 2011) and are often a prelude to tougher immigration laws, baring the door to newer migrants and encouraging existing migrants to fear the arrival of new cohorts who might threaten their right to remain. Furthermore, regularisations are a useful intelligence-gathering tool, allowing the state to collect data on migrants and both to locate and track them (Papademetriou and Sommerville, 2008). Regularisations that are employer-led hand immigration controls to employers who can determine who stays and who goes and can make an individual's regularisation dependent on how compliant they are in the job. Regularisation thus becomes an important bargaining chip for employers who can make deals with workers in return for the documents necessary to acquire legal status. In Italy, for example, our data revealed that bogus firms were issuing fraudulent contracts to migrants to enable them to qualify for regularisation, boosting the market for fraudulent documents and increasing their costs to the migrant. Whether or not states regularise there are costs implications. If regularisation is proposed the state needs to determine how it will deal with those who do not meet the criteria for regularisation. In the mass regularisations that took place in Italy and in Spain one in ten applicants for regularisation did not obtain it. In those cases it appears that no action was taken against those whose regularisation request failed but this was in a period when the political climate was not as hostile to migration as it is today.

In terms of the effects of the regularisation programmes on migrant workers, an immediate improvement may be experienced in terms of psychological welfare, together with a right of access to the regulated market and to state welfare and services. Long-term effects are likely to be a combination of time and post regularisation enforcement measures that promote improvements in the life and work of regularised migrants. 


\section{Conclusion}

This paper addressed the complex relationship between regularised migration status and work conditions, including access to employment and social rights, utilising in-depth interviews with migrant workers in seven EU countries. As explained in the methodology section, particular care was taken in seeking to compare these findings, given the distinctiveness of the national contexts.

Legislative changes on immigration play an important role in determining the rights of an individual but the way that labour markets operate is crucial in creating spaces for undocumented workers to live and work in a country. The employment profile of the regularised migrants surveyed was characterised by work not only in the primary sector of the economy but also in the informal sector and in the periphery zones between the two. Status affects entitlement to rest breaks and has an impact on health and accidents. An alarming finding emerged that even though some migrants had managed to secure legal status, they remained trapped somewhere between the formal and informal labour market, working for employers who would not pay them their actual hours of work or would fail to pay the necessary social security contributions. Conversely, some legal migrants had chosen the 'freedom' of the informal contacts.

Regularisation has been used by some Member States, in the absence of a strong industrial relations system to enforce rights at work; however, regularisation by itself cannot eliminate inequality. Four factors emerged that may impede positive outcomes from regularisation and they related mainly to a combination of a lack of weakening of employment law and enforcement and general lack of vertical work mobility: an under-regulated industrial relations environment where trade unions are weak and unable to force employers to comply with labour standards; an absence of effective enforcement mechanisms, safeguarded by the state; very few possibilities to move to new sectors of employment; and high levels of casual or temporary work and a large informal economy demanding work.

\section{Bibliography}

Abella, M. I. (2000). "Migration and employment of undocumented workers: do sanctions and amnesties work?". In: Dinar C. A. Gacher, and H. Waldrauch (eds.), Irregular Migration: dynamics, impact, policy options. Eurosocial reports, 67. Vienna: European Centre for Social Welfare Policy and Research: 205-215.

Bansak, C. (2016). 'Legalizing undocumented immigrants, while legalization benefits most undocumented immigrants, deciding how to regularize them is challenging', IZA World of Labor, March 2016, http://wol.iza.org (Accessed: 26 August 2016).

Bloch, A. and Chimienti, M. (2011). "Irregular Migration in a globalising world", Ethnic and Racial Studies, 34(8): 1271-1285.

Bloch, A. and McKay, S. (2016). Living on the margins, undocumented migrants in a global city, Policy Press, Bristol 
Bohning, W. R. (1996). Employing foreign workers: a manual on policies and procedures of special interest to middle and low income countries, Geneva: International Labour Organisation.

Cobb-Clark, D. A. and Kossoudji, S. A. (1999). "Did legalization matter for women? Amnesty and the wage determinants of formerly unauthorized Latina workers", Gender Issues, 17(4): 314.

Cook, M.L., Gleeson, Sh., Griffith, K.L., and Kahn, L.M. (2018) "Introduction to a special issue on the impact of immigrant legalization initiatives: international perspectives on immigration and the world of work", ILR Review, 71(4): 807-822.

Dzhengozova, M. (2009). "Report Bulgaria". In: Baldwin-Edwards, M. and Kraler, A. (eds.), REGINE: Regularisations in Europe. Study on practices in the area of regularisation of illegally staying third-country nationals in the Member States of the EU, Appendix A: Country studies, Vienna: ICMPD.

ETUC. (2014). Position on the new European Commission's five-year programme on migration (EC Communication “An Open and Secure Europe: Making It Happen”), ETUC, Position Document.

European Commission (2015). Communication from the Commission to the European Parliament, the Council, the European Economic and Social Committee and the Committee of the Regions: a European agenda on migration, Brussels, 13.5.2015 COM (2015) 240 final.

European Commission (2016). Research on migration: facing realities and maximising opportunities, European Commission, Directorate-General for Research and Innovation.

European Commission (2018). Managing Migration in all its aspects. Commission note ahead of the June European Council 2018, https://ec.europa.eu/commission/sites/beta-political/files/eucomigration-booklet-june2018_en.pdf (Accessed: 15 August 2018)

European Parliament (2016). Exploring new avenues for legislation for labour migration to the $E U$, Directorate General for Internal Policies, Policy Department C: Citizens' Rights and Constitutional Affairs, Civil Liberties, Justice and Home Affairs. 
Mc Govern, C. (2014). EU Regularization Programmes: An Effective Tool to Manage 'Irregular Migration?', United Nations University, https:/ourworld.unu.edu/en/eu-regularization-programmes-aneffective-tool-to-manage-irregular-migration (Accessed: 10 August 2018).

McKay, S., Markova, E. and Paraskevopoulou, A. (2011). Undocumented workers' transitions: Legal status, migration, and work in Europe, New York: Routledge.

Menjívar, C. and Lakhani, S. M. (2016). "Transformative effects of immigration law: immigrants' personal and social metamorphoses through regularization", American Journal of Sociology, 121(6): 1818-1855.

MRCI. (2016). Migrant Rights Centre Ireland (MRCI) proposes regularisation scheme, Press centre, 3 May 2016.

Papademetriou, D. and Somerville, W. (2008). "Earned amnesty: bringing illegal workers out of the shadows", CENTRE: FORUM.

Passel, J. S. and Cohn, D. (2016). Overall number of U.S. unauthorized immigrants holds steady since 2009. Washington, DC: Pew Research Centre. Accessed at:

http://www.pewhispanic.org/2016/09/20/overall-number-of-u-s-unauthorized-immigrants-holdssteady-since-2009/

Piore, M. J. (1980). "Dualism as a response to flux and uncertainty". In: S. Berger and M. J. Piore (eds.) Dualism and discontinuity in industrial society, Cambridge: Cambridge University Press.

REGINE (2009). Regularisations in Europe. Study on practices in the area of regularisation of illegally staying third-country nationals in the Member States of the EU, Vienna: ICMPD, http:/ec.europa.eu/home-affairs/doc_centre/immigration/docs/studies/regine_ appendix_a_january_2009_en.pdf(Accessed: 14 August 2018).

Ruhs, M. and Wadsworth, J. (2018). "The impact of acquiring unrestricted work authorization on Romanian and Bulgarian migrants in the United Kingdom", ILR Review, 71(4): 823-852. 
Siegmann, F. A. and Schiphorst, F. (2016). "Understanding the globalizing precariat: from informal sector to precarious work", Progress in Development Studies, 16(2): 111-123.

Thebe, V. (2016). "'Two steps forward, one step back': Zimbabwean migration and South Africa's regularising programme (the ZDP)", Int. Migration \& Integration doi:10.1007/s12134-016-0495-8pp.

Visser, M. (2016). "Reshaping migrant labour market geographies: local regularisations and the informal economy", Population, Space and Place, DOI: 10.1002/psp. 